\title{
29. A New Inoceramid (Bivalvia) Species from the Upper Cretaceous of Northeast Japan
}

\author{
By Tatsuro Matsumoto and Ryozo Sugiyama \\ (Communicated by Teiichi Kobayashi, M. J. A., March 12, 1985)
}

During a geological field-work in the Upper Cretaceous outcrops at and near Taneichi (Iwate Prefecture) on the Pacific coast of Northeast Japan, one of us (R.S.) obtained several specimens of the bivalvian family Inoceramidae. After a preliminary study, they were sent to the other of us (T.M.) for more careful palaeontological investigation. Through this study it has become clear that they represent an interesting new species of Sphenoceramus. In this paper we report a result of our study.

Before going to the palaeontological description, a short note on the stratigraphy is given. A series of strata which extends in a narrow belt along this coast is called the Taneichi Formation. As is shown in Fig. 1, they incline gently eastward, resting on the granitic basement ( $G$ in Fig. 1) with an unconformity. The Taneichi Formation $(T)$ is divisible into the following three units in ascending order.

(1) Uge Member (U) : conglomerate and sandstone, with layers of tuff and coal or coaly shale, about $20 \mathrm{~m}$.

(2) Okonai Member (O) : sandstone predominant, with lenticular conglomerate and Crassostrea banks in the lower part and muddy fine-

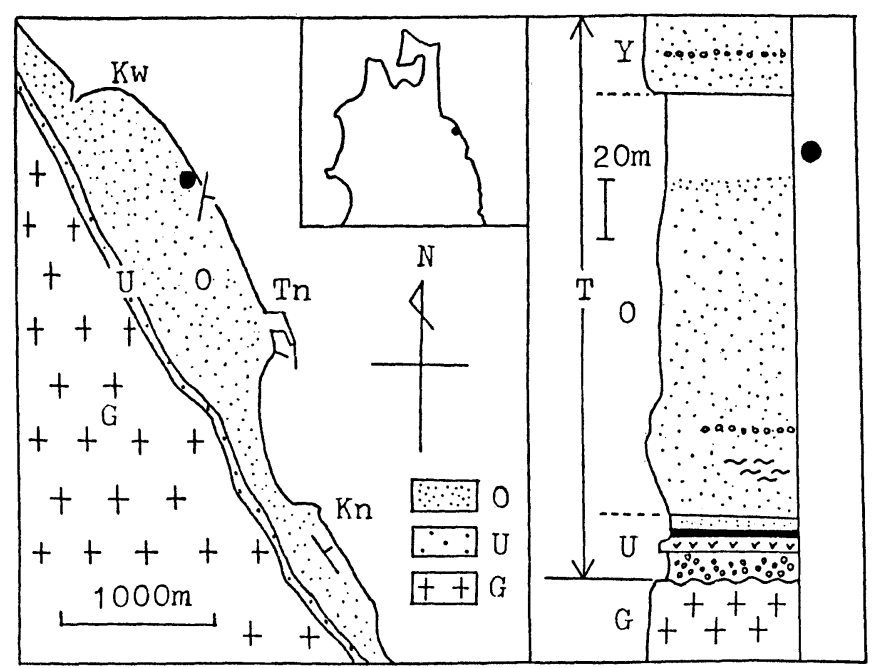

Fig. 1. Geological map and columnar section, showing the location of Sphenoceramus sanrikuensis sp. nov. with a solid circle. O, U, G, see text; Kw, Kawashiri, Tn, Taneichi; Kn, Kanuka. Lithologic symbols in the columnar section-small empty circle, conglomerate; small v, tuff; black band, coal or coaly shale; dots, sandstone; blank, muddy fine-sandstone; wavy line, Crassostrea bank. 
grained sandstone with marine fossils in the upper part, $140 \mathrm{~m}$.

(3) Yagi Member ( $\mathrm{Y}$ ) : massive sandstone, $25 \mathrm{~m}$ (exposed part).

The Taneichi Formation was once considered as Tertiary, but later revised to the Upper Cretaceous on the evidence of ammonoids (Polyptychoceras etc.) and inoceramids by Terui et al. (1975). It is approximately correlated with the better known Upper Cretaceous Kuji Formation in the south and the Okonai Member resembles generally the Kunitan Member, middle part of the Kuji Formation, in the latter of which Inoceramus (Platyceramus) japonicus Nagao et Matsumoto occurs among others, indicating the late Santonian age. The inoceramid specimens described below were embedded in the upper part of the Okonai Member.

\section{Palaeontological description.}

Family Inoceramidae Zittel, 1881

Genus Sphenoceramus Böhm, 1915

Sphenoceramus sanrikuensis sp. nov.

Holotype:-Internal mould of a left valve, "A" (Fig. 2).

Paratypes:-External (B) and internal (C) moulds of a right valve and five other specimens (internal moulds) ( $\mathrm{D}$ to $\mathrm{H}$ ) in the same rock mass as the holotype. They are kept at the Museum of Iwate Prefecture, Morioka.

Diagnosis:-Shell small, moderately convex, extending obliquely to the posteroventral extremity, with straight growth-axis which forms angle $(\delta)$ of about $65^{\circ}$ with the hinge-line. Posterior wing fairly broad, definitely demarcated from the main part of disk. Hinge-line about a half of shell-length, with obtuse

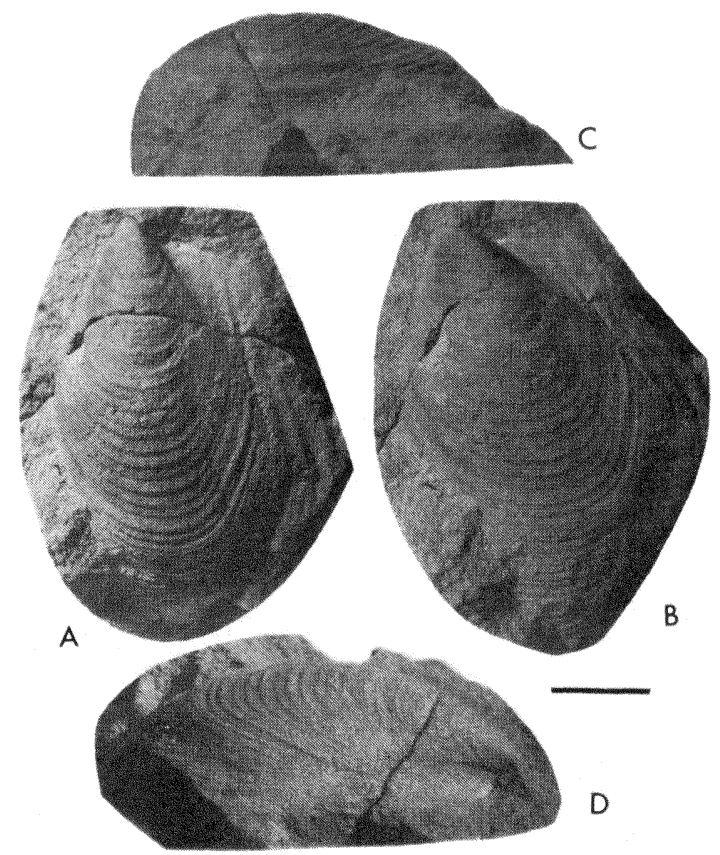

Fig. 2. Sphenoceramus sanrikuensis sp. nov. Holotype (internal mould) : Two slightly different lateral (A, B), anterior (C) and posterior (D) views. Scale bar $=10 \mathrm{~mm}$. (Photos by R. Sugiyama.) 
anterior angle $\left(\alpha=105^{\circ}\right)$ and posterior one $\left(\gamma=125^{\circ}\right)$, but angle $(\beta)$ of umbonal inflation acute $\left(63^{\circ}\right)$. Anterior margin nearly straight or very gently arcuate; ventral margin asymmetrically and fairly narrowly rounded; posterior margin long and straight. A shallow radial sulcus normally developed on the posterior part of disk. Main part of disk ornamented with numerous, regular concentric rings, some of which may be united near the margin but do not show typical doubling. Those on the ventral part finer and more crowded than those on the main part. Concentric major undulations faint or almost undeveloped. Several lines run on the posterior wing in parallel with posterior margin.

Etymology:-Sanriku is the region covering the three Prefectures, Miyagi, Iwate, and Aomori, on the Pacific side of northeastern Japan.

Measurements (in $\mathrm{mm}$ ):-

\begin{tabular}{ccccccccccc}
\hline Specimen & $\mathrm{h}$ & $\mathrm{l}$ & $\mathrm{l} / \mathrm{h}$ & $\mathrm{H}$ & $\mathrm{L}$ & $\mathrm{L} / \mathrm{H}$ & \multicolumn{1}{c}{$\mathrm{b}$} & $\mathrm{b} / \mathrm{h}$ & $\mathrm{s}$ & $\mathrm{s} / \mathrm{l}$ \\
$\mathrm{A}$ & 36.4 & 26.0 & .71 & 37.0 & 27.0 & .73 & 12.5 & .34 & 13.7 & .53 \\
$\mathrm{C}$ & 31.0 & 24.6 & .79 & 32.0 & 23.0 & .72 & 9.5 & .30 & 13.5 & .55 \\
\hline
\end{tabular}

For letters see Matsumoto and Noda (1985).

Comparison:-This species resembles S. naumanni (Yokoyama, 1890) (see Nagao and Matsumoto, 1940), but is distinguished by its broader posterior wing, longer hinge-line, larger anterior hinge angle and absence of typical double-rings. It is closely allied to $S$. africanus (Heinz, 1933) (see Sornay, 1964) from the Santonian of Madagascar, but the latter is somewhat larger and provided with regular combination of concentric rings and major ribs.

Occurrence:-See note on stratigraphy. It is noted that S. sanrikuensis occurs in the sandy sediments of near shore shallow sea facies, whereas $S$. naumanni is common in the muddy sediments of off-shore facies.

Acknowledgements. We wish to thank Drs. Jacques Sornay, Masayuki Noda and Messrs. Kazuaki Terui and Seiichi Toshimitsu for their help to this study, as well as Professor Emeritus Teiichi Kobayashi, M. J. A., for his continuous encouragement.

\section{References}

Böhm, J. (1915) : Zeitsch. deutsch. geol. Gesell., 65, Mh., 182-183 (for 1914).

Heinz, R. (1933) : ibid., 85, 241-259.

Matsumoto, T., and Noda, M. (1985): Proc. Japan Acad., 61 B, 9-11.

Nagao, T., and Matsumoto, T. (1940) : Jour. Fac. Sci., Hokkaido Imp. Univ., ser. 4, 6(1), 1-64.

Sornay, J. (1964) : Ann. Paléont., Invertébrés, 50, 167-179.

Terui, K. et al. (1975) : Jour. Geol. Soc. Japan, 81, 783-785.

Yokoyama, M. (1890): Palaeontographica, 36, 159-202. 